\title{
Prevention of Anemia in Pregnant Women after Periodic Deworming with Albendazol and Praziquantel (Review)
}

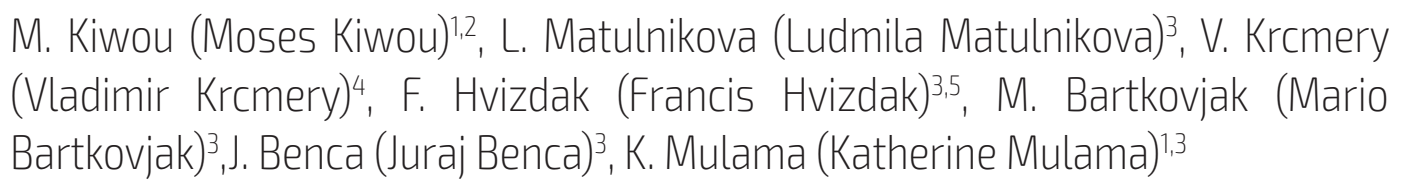

${ }^{1}$ Sisters of Mercy Centre of Obstetrics, St, Lesley Clinic Project,

Original Article

Naiwasha, Kenya

${ }^{2}$ Maternity Ward, Gordim, SAMRS and SEU Tropicteam, Slovakia

${ }^{3}$ St. Elizabeth Univ program St. Lesley College, Nove Zamky, Slovakia

${ }^{4}$ School of Medicine, Inst. of Microbiology, Comenius University in Bratislava, Slovakia

${ }^{5}$ St. Charles Lwanga Hospital, Czech Charity and SEU Tropical Program, Buikwe, Uganda

\section{E-mail address:}

tropicteam@gmail.com

\section{Reprint address:}

Catherine Mulama

St, Lesley Clinic Project

Naiwasha

Kenya

Source: Clinical Social Work and Health Intervention

Pages: $75-77$
Volume: 9

Cited references: 4

Issue: 4

\section{Reviewers:}

Andrea Shahum MD

UNC Chapel Hill, North Carolina, USA

\section{Key words:}

Pregnancy. Anemia.

\section{Publisher:}

International Society of Applied Preventive Medicine i-gap

CSWHI 2018; 9(4): 75 - 77; DOI 10.22359/cswhi_9_4_12 @ 2018 Clinical Social Work and Health Intervention

\section{Abstract:}

The Aim of this research was to assess the effect of preventive administration of anti-parasitic drug against anemia during pregnancy in Kenyan pregnant women in St. Lesley Clinic in Eldoret, within 10 years 
after introducing the strategy of two administration of albendazole and praziquantel during their pregnancy check up in the beginning of $2^{\text {nd }}$ and $3^{\text {rd }}$ trimester.

\section{Introduction}

Anaemia is the leading cause of maternal mortality after delivery in Sub-Saharan Africa and is responsible for majority of maternal and neonatal deaths.(1) The Aim of this research was to assess the effect of preventive administration of anti-parasitic drugs against anemia in pregnancy in Kenyan pregnant women in St. Lesley Clinic in Eldoret, within 10 years after introducing the strategy of two administration of albendazole and praziquantel during their pregnancy check up in the beginning of $2^{\text {nd }}$ and $3^{\text {rd }}$ trimester. Several studies have been published on the positive effect of IPT with sulfadoxine-pyrimethamine against malaria related anemia $(1,2)$ but not on PT.

\section{Major Causes of Maternal Anemia in Developing Countries}

\section{Malnutrition}

Malnutrition is the major cause of anemia both in mothers and children in Sub-Saharan Africa caused by reduced uptake of elements, which are mandatory for erythropoesis (folic acid, iron, cobalt, vitamin B6, B12, etc.). Therefore to combat malnutrition and anemia is one of the millennium development goals and 2030 agenda by WHO.

\section{Dietary customs}

Vegetarians are especially common in several South Asia countries (India, etc.) Reduced in-take of meat proteins may cause vitamin B12 and iron mild to severe anemia especially when combined with malnutrition and malaria. Affordability of proteins is questionable in Sub-Saharan Africa too, especially in countries with famine, such as South Sudan.

\section{Malaria}

In Sub-Saharan Africa malaria is the leading cause of both mother and child anemia is due to one or more hemolytic effects.

\section{AIDS and Chronic ID (TBC)}

Consumption of elements and blood cells by ARV or other drugs for chronic infections as well as bone marrow suppression during antiretroviral chemotherapy for HIV/AIDS may contribute to anemia. Prophylactic co-trimoxazole and AZT in ART may cause severe anemia and thrombocytopenia.

\section{Geohelminth Parasites}

Consuming B12 (Hookworm - A. duodenale) and proteins (Ascaris, Trichuris, Taenia spp.) infection with geohelminths may contribute, especially in malaria endemic countries, to severe anemia. Therefore, an administration $2 \mathrm{x}$ in pregnancy during regular check up ( $2^{\text {nd }}$ and $3^{\text {rd }}$ trimester $)$ combination of albendazole and praziquantel.

\section{Conclusion}

Periodic deworming, food programs where needed and anti-parasitics administration decrease significantly anemia in pregnancy. 


\section{References}

1. TAYLOR-ROBINSON DC, MAAYAN N, SOARES-WEISER K, DONEGAN S, GARNER P (2012) Deworming drugs for soil-transmitted intestinal worms in children: effects on nutritional indicators, hemoglobin and school performance. Cochrane Database Syst Rev. Jul 11; (7): CD000371. doi: 10.1002/14651858.CD000371.pub4. Review. Update in: Cochrane Database Syst Rev. 2012;11:CD000371. PubMed PMID: 22786473.

2. BUNDY DAP, APPLEBY L J, BRADLEY M, CROKE K, HOLLINGSWORTH TD, PULLAN R, TURNER HC, SILVA ND (2017) Mass Deworming Programs in Middle Childhood and Adolescence. In: Bundy DAP, Silva ND, Horton S, Jamison DT, Patton GC, Editors (2017) Child and
Adolescent Health and Development 3rd Edition. Washington (DC): The International Bank for Reconstruction and Development / The World Bank; Nov. 20. Chapter 13. PubMed PMID: 30212135.

3. HALUSKOVA E, BOZIK J (2015) Poverty, Social Context and Social Policies to Eliminate It. Bratislava: IRIS, 244 pp. 978-808153-040-1.

4. AHUJA A, BAIRD S, HICKS JH, KREMER M, MIGUEL E (2017) Economics of Mass DewormingPrograms. In: Bundy DAP, Silva ND, Horton S, Jamison DT, Patton GC, Editors. Child and Adolescent Health and Development. 3rd edition. Washington (DC): The International Bank for Reconstruction and Development / The World Bank; Nov. 20. Chapter 29. PubMed PMID: 30212124. 